\title{
Multisystem inflammatory syndrome in children during the coronavirus disease pandemic of 2019: a review of clinical features and acute phase management
}

\author{
Naohiro Shioji ${ }^{1,2} \cdot$ Kazuyoshi Aoyama $^{3,4} \oplus \cdot$ Marina Englesakis $^{5} \cdot$ Gail Annich $^{1} \cdot$ Jason T. Maynes ${ }^{3,6}$
}

Received: 5 February 2021 / Accepted: 22 May 2021 / Published online: 30 May 2021

(c) Japanese Society of Anesthesiologists 2021

\begin{abstract}
The current coronavirus disease of 2019 (COVID-19) pandemic has presented unique health challenges in the pediatric population. Compared to adults, the most significant change in viral disease manifestation is encompassed by the multisystem inflammatory syndrome in children (MIS-C). MIS-C is a new inflammatory syndrome which develops 2-4 weeks after COVID-19 exposure, with evidence suggesting it is a post-infectious immune reaction. We describe its epidemiology, pathophysiology, diagnosis (which varies based on definition used) and treatment options based on published recommendations. A systematic literature search we conducted through MEDLINE yielded 518 abstracts and identified five studies that reported more than 100 cases of MIS-C and their mortality. Most cases developed multiorgan dysfunction, including cardiovascular, dermatologic, neurological, renal, and respiratory issues, and required intensive care unit (ICU) admission. Many patients admitted to the ICU needed inotrope support and invasive mechanical ventilation, and the most severe cases required extracorporeal membrane oxygenation support. Most clinicians treated MIS-C with intravenous immunoglobulin, systemic steroids, and biological therapies. Overall mortality was low (2-3\%) in all studies. Further research is needed to: understand if early intervention can prevent its progression; optimize its treatment; and improve outcomes of this new syndrome for the patients who develop MIS-C.
\end{abstract}

Keywords MIS-C · COVID-19 $\cdot$ Shock $\cdot$ Children

Kazuyoshi Aoyama

kazu.aoyama@utoronto.ca

1 Department of Critical Care Medicine, The Hospital for Sick Children, University of Toronto, Toronto, Canada

2 Department of Critical Care Medicine, Okayama University Hospital, Okayama, Japan

3 Department of Anesthesia and Pain Medicine, The Hospital for Sick Children, University of Toronto, Toronto, Canada

4 Program in Child Health Evaluative Sciences, SickKids Research Institute, Toronto, Canada

5 Library and Information Services, University Health Network, Toronto, Canada

6 Program in Molecular Medicine, SickKids Research Institute, Toronto, Canada

\section{Introduction}

The current coronavirus disease of 2019 (COVID-19) pandemic has presented unique health challenges in the pediatric population [1]. Compared to adults, the most significant change in viral disease manifestation is encompassed by the multisystem inflammatory syndrome in children (MIS-C). The syndrome consists of a collection of primarily hyperinflammatory pathologies that can involve multiple organs, but most significantly affects the cardiovascular, hematologic, and gastrointestinal systems [2]. Riphagen et al. first reported MIS-C cases in eight previously healthy children with hyperinflammation and shock, who presented with symptoms similar to those of Kawasaki disease, including coronary vasculitis [3]. Given the non-specific constellation of symptoms and lab findings involved in the syndrome (and the need for a positive COVID-19 test), both diagnosis and treatments, including resuscitation, have presented 
challenges. This special article describes the epidemiology, pathophysiology, diagnosis, and detailed treatment of MIS-C based on published studies and case reports. We also present updated evidence of clinical outcomes in children with MIS-C based on a systematic literature search, and discuss future clinical and research implications.

\section{Epidemiology}

Overall incidence of COVID-19 in children has been reported to be low $(5 \%, 36$ pediatric cases out of 661 adult and pediatric cases with COVID-19) [4]. Beyond a lower overall incidence, lower respiratory tract infection also tends to manifest less severe symptoms in children compared to adults [4-7]. While only a small percentage of pediatric patients require ICU admission (1.7\%) [6], a large portion of children that do require ICU care possess comorbidities (83\%), including medical complexity, immune suppression/ malignancy, and obesity [7].

A strong epidemiologic association exists between COVID-19 and a hyperinflammatory response which develops in some children, defined as MIS-C. Clinically, MIS-C manifests 2-4 weeks after COVID-19 exposure, although the percentage of cases where the virus was detected by reverse transcriptase polymerase chain reaction is low (14.5-51\%), while the percentage of positive serology is high (31-99\%) [2, 8-12]. Based on a New York State study, the total incidence of MIS-C was low at 2 per 100,000 persons, while laboratory-diagnosed COVID-19 in children was 322 per 100,000 persons [8], illustrating the relative rarity of the hyperinflammatory condition. Most children who develop MIS-C have been previously healthy (78\%), yet a majority of cases required ICU admissions (21-80\%) [2, 8-12].

\section{Pathophysiology}

The pathophysiology of MIS-C is not yet completely established. The initial phase starts with the virus invading into the respiratory tract through the angiotensin-converting enzyme-2 (ACE-2) receptor. Often, COVID-19 fails to progress beyond asymptomatic or minimal symptoms in children, probably due to lower expression of ACE-2 receptor (compared to adults) [13]. Given the time delay to presentation (2-4 weeks after viral symptoms), MIS-C is likely related to a post-infectious immune response, rather than a direct pathology of the virus. Several hypotheses of the pathophysiology of MIS-C have been advocated, including a delayed dysregulated immune response and superantigen activity. MIS-C may result from coronaviruses' ability to block type I and type III interferon responses [14], leading to a profound cytokine storm. One study noted that elevated interleukin (IL)-10 and tumor necrosis factor- $\alpha$ (TNF- $\alpha$ ) levels were more common in MIS-C patients, over those with just severe COVID-19 disease [15]. This same study found that MIS-C patients were more likely to have burr cells present on peripheral blood smears. A study of structure-based computational models by Cheng et al. demonstrated that the severe acute respiratory syndrome coronavirus 2 spike glycoprotein is similar to the bacterial superantigen staphylococcal enterotoxin B [16].

The pathophysiology of damage across affected organ systems (cardiovascular, dermatologic, neurological, renal, and respiratory systems) can be multifactorial, including secondary to hypovolemia, low cardiac output state, vasculitis, microthrombus, edema, or inflammation. Most common cardiovascular involvement is shock, cardiac arrhythmias, pericardial effusion, and coronary artery dilatation [17]. Cardiac involvement can result from a combination of inflammation, microthrombus, and myocardial edema. Acute kidney injury is secondary to hypovolemia or a low cardiac output state, or directly related to vasculitis or inflammation [18]. Respiratory failure can result from a combination of pulmonary edema and acute respiratory distress syndrome secondary to inflammation. With multiple organ systems often involved, MIS-C usually develops a mixed shock clinical picture, consisting of components of cardiogenic, hypovolemic, and distributive shock.

\section{Diagnosis}

The most common symptoms of MIS-C at presentation are fever, gastrointestinal manifestations (i.e., pain, nausea, vomiting, and diarrhea), oral mucosa changes and rash, although many cases have presented directly with vasodilatory shock $[2,19]$. Most patients show remarkably elevated inflammatory makers, including C-reactive protein (CRP), ferritin, and procalcitonin [8]. There are four different definitions of MIS-C from national and international agencies, including the World Health Organization (WHO) [20], the United States Centers for Disease Control and Prevention (CDC) [21], the Royal College of Pediatrics and Child Health (RCPCH, UK) [22], and The Canadian Paediatric Surveillance Program (CPSP) [23] (Table 1). Although slightly different, these definitions rely on a combination of physiological and laboratory findings, in most cases requiring the finding of a COVID-19 infection (past or current). Given the lack of a specific marker or diagnostic test for MIS-C, all definitions require the exclusion of other probable causes. As mentioned, the generalized inflammation can affect multiple organ systems, and a broad scope needs to be used to discover the presence of involvement in any one individual. Cardiac involvement is high, with the potential for life-threatening dysfunction. A large proportion of patients 
Table 1 Comparison of the definitions for multisystem inflammation syndrome in children among four organizations

\begin{tabular}{lllll}
\hline & WHO [20] & CDC (US) [21] & RCPCH (UK) [22] & CPSP (Canada) [23] \\
\hline Age & 0-19 years & $<21$ years & Child & $<18$ years \\
& & & Age not specified & \\
Length of fever & $\geq 3$ days & $\geq 24 \mathrm{~h}$ & Not specified & $\geq 3$ days \\
Elevated makers of inflammation & Yes & Yes & Yes & Yes \\
Number of organs involved & $\geq 2$ & $\geq 2$ & $\geq 1$ & Not specified \\
Exclusion of other causes & Yes & Yes & Yes & Yes \\
RT-PCR positive or serology & Necessary & Necessary & Not necessary & Necessary \\
positive or contact with case & & & & \\
\hline
\end{tabular}

CDC Centers for Disease Control and Prevention (US), CPSP Canadian Paediatric Surveillance Program (Canada), RCOCH Royal College of Paediatrics and Children Health (UK), RT-PCR reverse transcription polymerase chain reaction, $U K$ The United Kingdom, US The United States of America, WHO World Health Organization

${ }^{a}$ Markers of inflammation may include C-reactive protein, procalcitonin and ferritin
(39\%) develop acute coronary artery abnormalities [10]. Echocardiography to assess heart function and coronary artery anatomy is essential, especially when a patient has known cardiac dysfunction or elevated troponin I and B-type natriuretic peptide (BNP). There is no current understanding if longitudinal follow-up with echocardiography is needed if the initial assessment is negative (as with Kawasaki disease, more below).

Excluding other potential causes of hyperinflammatory illness is essential. MIS-C has overlapping clinical findings with Kawasaki disease, and features similar to septic shock, toxic shock syndrome, macrophage activation syndrome, and enterovirus-causing myocarditis. Excluding ongoing infectious disease is critical since anti-immunomodulating therapy such as systemic steroid and biologic therapies is an important treatment for MIS-C [24]. Kawasaki disease is a syndrome that causes vasculitis in young children $(76 \%$ of the cases are in children less than 5 years). The diagnosis of Kawasaki disease is based on clinical features, including fever, erythema, strawberry tongue, bulbar conjunctival injection, rash, edema of the hands and feet in the acute phase, periungual desquamation in the subacute phase, and cervical lymphadenopathy [25-27]. The main difference between MIS-C and Kawasaki disease is that individuals with MIS-C are older; more likely to present with shock; have higher white blood cells, CRP, and troponin; have a higher likelihood of cardiac involvement and have a proximal diagnosis of or exposure to COVID-19 [10, 28].

\section{Treatment}

MIS-C is a new syndrome, and there is no standard-of-care treatment yet. Based on clinical experience in the treatment of other disorders with hyperinflammation and vasculitis, assessed treatments include intravenous immunoglobulin (IVIG), systemic steroids, and biological therapies. The latter can include treatments that specifically target IL-1 (anakinra), IL-6 (tocilizumab), and TNF- $\alpha$ (infliximab) [29], or have wider anti-inflammatory effects like convalescent plasma or stem cell injections.

Since MIS-C may involve a variety of organ systems, treatment should be tailored to each case, and a multi-disciplinary approach is crucial. Medications recommended for MIS-C are summarized in Table 2. A local guideline from a pediatric specialty hospital in NY, U.S. recommends treatment with a single dose of IVIG $(2 \mathrm{~g} / \mathrm{kg})$ and aspirin $(20-25 \mathrm{mg} / \mathrm{kg} / \mathrm{dose}$ every $6 \mathrm{~h}$ ) for all patients with Kawasaki disease-like illness [30]. The American College of Rheumatology recommends high-dose IVIG $(2 \mathrm{~g} / \mathrm{kg})$ and lowto-moderate-dose intravenous methylprednisolone (1-2 mg/ $\mathrm{kg}$ /day) as first-line therapy for MIS-C patients with shock or organ-threatening disease, even before completion of the full diagnostic evaluation. When the disease is refractory to these first-line treatments, high-dose intravenous methylprednisolone (10-30 mg/kg/day) or high-dose anakinra ( $>4 \mathrm{mg} / \mathrm{kg} /$ day intravenous or subcutaneous) has been used [31]. In a recent systematic review, $76 \%$ of patients received IVIG, and $11 \%$ required multiple IVIG doses [32]. When a patient is at a high risk of developing coronary aneurysms, it has been suggested that high-dose intravenous methylprednisolone $(30 \mathrm{mg} / \mathrm{kg} / \mathrm{day})$ should be administered [30]. If the first-line treatments fail, a second dose of IVIG or biological therapies should be considered [30, 33]. However, there is controversy regarding a second dose of IVIG. The American College of Rheumatology does not recommend a second dose of IVIG due to the risk of volume overload and hemolytic anemia associated with high-dose IVIG [31].

A high percentage of children who are admitted to the ICU with MIS-C present in shock (87\%), making initial hemodynamic resuscitation efforts key to improving outcomes [9]. Resuscitation can include fluid resuscitation, inotropic support, and invasive mechanical ventilation, with the most severe cases requiring extracorporeal membrane 
Table 2 Summary of treatment for MIS-C proposed by three groups

The Rheumatology Study Group of the Italian Society of American College of Rheumatology [31] Western New York [30] Pediatrics [33]

\begin{tabular}{|c|c|c|c|}
\hline IVIG & $2 \mathrm{~g} / \mathrm{kg} /$ day (up to $70-80 \mathrm{~g}$ ) ${ }^{\mathrm{a}}$ & $2 \mathrm{~g} / \mathrm{kg} / \mathrm{day}^{\mathrm{b}}$ & $2 \mathrm{~g} / \mathrm{kg} / \mathrm{day}^{\mathrm{c}}$ \\
\hline Corticosteroids & $\begin{array}{l}\text { 1) } \mathrm{mPSL} 1 \mathrm{mg} / \mathrm{kg} / \mathrm{dose} \mathrm{q} 12 \mathrm{~h} \mathrm{IV} \\
\text { 2) } \mathrm{mPSL} 30 \mathrm{mg} / \mathrm{kg} / \mathrm{dose}(\max 1 \mathrm{~g}) \mathrm{q} 24 \mathrm{~h} \text { IV for } 1-3 \text { days } \\
\text { 3) Dexamethasone } 10 \mathrm{mg} / \mathrm{m}^{2} \mathrm{q} 24 \mathrm{~h}\end{array}$ & $\begin{array}{l}\text { 1) } \mathrm{mPSL} 1-2 \mathrm{mg} / \mathrm{kg} / \mathrm{day} \\
\text { 2) } \mathrm{mPSL} 10-30 \mathrm{mg} / \mathrm{kg} / \text { day }\end{array}$ & Pulse mPSL with taper ${ }^{\mathrm{f}}$ \\
\hline Aspirin & $5 \mathrm{mg} / \mathrm{kg} /$ day for at least $6-8$ week $^{\mathrm{g}}$ & $3-5 \mathrm{mg} / \mathrm{kg} /$ day, maximum $81 \mathrm{mg} /$ day $^{\mathrm{h}}$ & $20-25 \mathrm{mg} / \mathrm{kg} / \mathrm{dose} \mathrm{q} 6 \mathrm{~h}^{\mathrm{i}}$ \\
\hline Anakinra & $\begin{array}{l}\text { 1) } 4-6 \mathrm{mg} / \mathrm{kg} / \mathrm{dose} \text { q24h SCj } \\
\text { 2) } 2 \mathrm{mg} / \mathrm{kg} / \mathrm{dose}(\max 100 \mathrm{mg} / \text { dose) q } 6 \mathrm{hIV} \\
\text { 3) } 2 \mathrm{mg} / \mathrm{kg} / \mathrm{dose}(\max 100 \mathrm{mg} \text { ) IV pulse followed by } \\
\text { continuous infusion at a total daily dose of no more than } \\
12 \mathrm{mg} / \mathrm{kg} \text { or } 400 \mathrm{mg}\end{array}$ & $>4 \mathrm{mg} / \mathrm{kg} /$ day IV or $\mathrm{SC}^{\mathrm{k}}$ & $\begin{array}{l}\text { Consider when there } \\
\text { was a failure of first- } \\
\text { line treatment }\end{array}$ \\
\hline Tocilizumab & $\begin{array}{l}\text { In case of acute kidney failure and evidence of microangi- } \\
\text { opathy }\end{array}$ & There is insufficient evidence & Not mentioned \\
\hline Infliximab & Dose not mentioned & There is insufficient evidence & $\begin{array}{l}\text { Consider when there is } \\
\text { a failure of first-line } \\
\text { treatment }\end{array}$ \\
\hline
\end{tabular}

$I V I G$ intravenous immunoglobulin, $m P S L$ methylprednisolone, $I V$ intravenous injection, $S C$ subcutaneous injection, $M I S-C$ multisystem inflammatory syndrome in children, $s H L H$ secondary hemophagocytic lymphohistiocytosis

${ }^{a}$ Recommended to be administered over at least $12 \mathrm{~h}$, a second dose of IVIG should be considered in case of inadequate response

${ }^{\mathrm{b}} \mathrm{A}$ second dose of IVIG is not recommended

${ }^{\mathrm{c}}$ Recommend for all patients with KD-like illness, consider a second dose when there is a failure of first-line treatment

${ }^{\mathrm{d}}$ 1) or 2) should be chosen depending on disease severity, based on clinical/laboratory features, 3) in case of sHLH or central nervous system involvement

${ }^{\mathrm{e}}$ 1) for the child with shock or organ-threatening disease, 2) for patient requires high-dose or multiple inotropes and/or vasopressors

${ }^{\mathrm{f}}$ For myocarditis/cardiogenic shock and/or distributive shock

${ }^{\mathrm{g}}$ In case coronary abnormalities are found

${ }^{\mathrm{h}}$ Should be used in patients with MIS-C and continues until the platelet count in normalized and normal coronary arteries are confirmed at $4>$ weeks after diagnosis

${ }^{\mathrm{i}}$ Recommend for all patients with Kawasaki disease-like illness

${ }^{\mathrm{j}} 1$ ) to be used SQ as second line treatment, in case of persistent disease activity $48 \mathrm{~h}$ after first-line treatment or in case of sHLH, 2)-3) to be used IV in adjunction to corticosteroids and IVIG in case of severe sHLH or shock with cardiac failure

${ }^{\mathrm{k}}$ For patients with refractory to IVIG and glucocorticoids and features of macrophage activation syndrome or for patients with contraindications to long-term use of glucocorticoids

oxygenation support (3.8\%) [9]. At this time, no data are available to determine if the use of aggressive non-invasive ventilation can prevent intubation and the need for invasive mechanical ventilation. Given the prevalence of gastrointestinal symptoms, non-invasive ventilation potentially risks aspiration for the patient.

\section{Summary of clinical outcomes of MIS-C}

We conducted a systematic literature search through MEDLINE on December 9, 2020 with an updated search on April 2, 2021, containing sets of terms reflecting our topic of interest, including the disease (COVID-19, severe acute respiratory syndrome coronavirus 2 (SARS-CoV-2)), MIS$\mathrm{C}$, pediatric patients, and large cohort studies, which yielded 518 abstracts (Supplementary online resource 1). From those
518 abstracts, we identified five studies that reported more than 100 cases of MIS-C and their mortality (Table 3).

Three studies used CDC criteria to diagnose MIS-C [2, $34,35]$ while other studies applied modified CDC criterion [36], and modified CDC and RCPCH [17]criterion. This variance in diagnostic criteria complicates comparison between studies. That said, most patient cohorts had high rates of cardiovascular involvement, and $30-48 \%$ of the cases required inotrope support (Table 3). The most utilized advanced therapy was the administration of IVIG and, despite disease severity, overall mortality was low $(0.3-2 \%)$ in all studies.

\section{Future implications}

MIS-C is a newly characterized syndrome, and optimal treatment is currently unknown. Whether early intervention (and exactly which intervention) can prevent severe 
Table 3 Summary of identified 5 large cohort studies reporting demographic and clinical outcomes of multisystem inflammatory syndrome in children (MIS-C)

\begin{tabular}{|c|c|c|c|c|c|}
\hline & Feldstein et al. [2] & $\begin{array}{l}\text { Bautista-Rodriguez } \\
\text { et al. [36] }\end{array}$ & Valverde et al. [17] & Feldstein et al. [34] & Abrams et al. [35] \\
\hline Study cohort & $\begin{array}{l}53 \text { hospitals across } \\
\text { the US }\end{array}$ & $\begin{array}{l}33 \text { hospitals in Euro- } \\
\text { pean, Asian, and } \\
\text { American countries }\end{array}$ & $\begin{array}{l}55 \text { centers in } 17 \text { Euro- } \\
\text { pean countries }\end{array}$ & $\begin{array}{l}66 \text { US hospitals in } 31 \\
\text { states }\end{array}$ & $\begin{array}{l}\text { State and local health } \\
\text { departments in the } \\
\text { US }\end{array}$ \\
\hline Study period & $\begin{array}{l}\text { March 15-May 20, } \\
2020\end{array}$ & $\begin{array}{l}\text { March 1-June 15, } \\
2020\end{array}$ & $\begin{array}{l}\text { February 1-June 6, } \\
2020\end{array}$ & $\begin{array}{l}\text { March 15-October } \\
31,2020\end{array}$ & March 11-Oct 10, 2020 \\
\hline $\begin{array}{l}\text { Number of MIS-C } \\
\text { patients }\end{array}$ & 186 & 183 & 286 & 539 & 1080 \\
\hline $\begin{array}{l}\text { Age (years) (median/ } \\
\text { mean) }\end{array}$ & 8.3 (IQR 3.3-12.5) & $7 \pm 4.7$ & 8.4 (IQR 3.8-12.4) & 8.9 (IQR 4.7-13.2) & 8 (IQR 4-12) \\
\hline $\begin{array}{l}\text { Coexisting conditions }{ }^{\mathrm{a}} \\
N(\%)\end{array}$ & $51(27)$ & $48(26)$ & $16(6)$ & $167(31)$ & 286 (26) obesity \\
\hline Diagnostic definition & CDC & $\mathrm{CDC}$ age $\leqq 18$ years & $\begin{array}{l}\text { Modified CDC } \\
\text { and } \mathrm{RCPCH}, \\
\text { age }<18 \text { years }\end{array}$ & $\mathrm{CDC}$ & CDC \\
\hline \multicolumn{6}{|l|}{ Diagnostic method } \\
\hline $\begin{array}{l}\text { RT-PCR positive } \\
\quad N(\%)\end{array}$ & $73(39)$ & 43/114 (38) & $90 / 268(34)$ & $281(52)$ & NA \\
\hline $\begin{array}{l}\text { Serology positive } \\
\quad N(\%)\end{array}$ & $58(31)$ & 95/110 (86) & $\begin{array}{l}41 / 260(16) \operatorname{IgM} \\
116 / 260(44) \mathrm{IgG}\end{array}$ & $409(76)$ & NA \\
\hline $\begin{array}{l}\text { Contact with case } \\
N(\%)\end{array}$ & $55(30)$ & NA & NA & NA & NA \\
\hline \multicolumn{6}{|l|}{ Organ involvement } \\
\hline $\begin{array}{l}\text { Any cardiovascular } \\
N(\%)\end{array}$ & $149(80)$ & $79(43)^{\mathrm{a}}$ & $286(100)$ & $359(67)$ & 392 (36) shock \\
\hline $\begin{array}{l}\text { Any gastrointestinal } \\
N(\%)\end{array}$ & $171(92)$ & $117(64)$ & $204(71)$ & $486(90)$ & $\begin{array}{l}693(64) \text { pain } \\
684(63) \text { vomiting } \\
573(53) \text { diarrhoea }\end{array}$ \\
\hline $\begin{array}{l}\text { Any respiratory } N \\
(\%)\end{array}$ & 131(70) & $71(39)$ & $\begin{array}{l}97(34)^{\mathrm{b}} \\
62(22)^{\mathrm{c}}\end{array}$ & $432(80)$ & $\begin{array}{l}287(27) \text { shortness of } \\
\text { breath }\end{array}$ \\
\hline $\begin{array}{l}\text { Any dermatologic } \\
N(\%)\end{array}$ & $110(59)$ & $120(66)$ & $179(63)$ & $360(67)$ & $584(54)$ \\
\hline $\begin{array}{l}\text { Any neurologic } N \\
(\%)\end{array}$ & NA & $22(12)$ & NA & $218(40)$ & NA \\
\hline $\begin{array}{l}\text { Acute kidney injury } \\
N(\%)\end{array}$ & NA & NA & NA & $9(2)$ & NA \\
\hline Thrombus $N(\%)$ & NA & NA & NA & $11(2)$ & NA \\
\hline $\begin{array}{l}\text { Coronary artery } \\
\text { abnormality } N(\%)\end{array}$ & $15 / 170(9)$ & $38(21)$ & $69(24)$ & $57 / 424(13)$ & $185(17)$ \\
\hline ICU admission $N(\%)$ & $148(80)$ & $26(14)$ & $162(57)$ & $398(74)$ & $648(60)$ \\
\hline \multicolumn{6}{|l|}{ Therapy } \\
\hline IVIG $N(\%)$ & $144(77)$ & $163(89)$ & 367 (78) & 415 (77) & NA \\
\hline $\begin{array}{l}\text { Systemic steroid } \\
\qquad N(\%)\end{array}$ & $91(49)$ & $105(57)$ & $80(28)$ & 374 (69) & NA \\
\hline $\begin{array}{l}\text { Biologic therapies } \\
N(\%)\end{array}$ & $38(21)$ & NA & NA & 32 (6) Tocilizumab & NA \\
\hline $\begin{array}{l}\text { Antiplatelet (Aspi- } \\
\text { rin) } N(\%)\end{array}$ & NA & $124(67)$ & $212(74)$ & $308(57)$ & NA \\
\hline $\begin{array}{l}\text { Anticoagulation } N \\
\quad(\%)\end{array}$ & $87(47)$ & $78(43)$ & $108(38)$ & 337 (63) & NA \\
\hline $\begin{array}{l}\text { Inotropic support } \\
\quad N(\%)\end{array}$ & $90(48)$ & $72(39)$ & $80(30)$ & $244(45)$ & NA \\
\hline HFNC $N(\%)$ & NA & NA & NA & $114(21)$ & NA \\
\hline
\end{tabular}


Table 3 (continued)

\begin{tabular}{llllll}
\hline & Feldstein et al. [2] & $\begin{array}{l}\text { Bautista-Rodriguez } \\
\text { et al. [36] }\end{array}$ & Valverde et al. [17] & Feldstein et al. [34] & Abrams et al. [35] \\
\hline $\begin{array}{l}\text { Non-invasive MV } \\
N(\%)\end{array}$ & $32(17)$ & NA & NA & $192(36)$ & NA \\
$\begin{array}{l}\text { Invasive MV } N(\%) \\
\text { ECMO } N(\%)\end{array}$ & $37(20)$ & $43(24)$ & NA & NA & NA \\
Outcomes & $8(4)$ & $4(2)$ & & $18(3)$ & NA \\
ICU LOS (days) & NA & NA & NA & $4(2-7)$ & NA \\
Death $N(\%)$ & $4(2)$ & $3(2)$ & $1(0.3)$ & $10(2)$ & $18(2)$ \\
\hline
\end{tabular}

Each cell presents number and percentage unless otherwise specified

$M I S-C$ multisystem inflammatory syndrome in children, $R T$ - $P C R$ reverse transcription polymerase chain reaction, IVIG intravenous immunoglobulin, HFNC high flow nasal cannula, $M V$ mechanical ventilation, ECMO extracorporeal membrane oxygenation, $I Q R$ interquartile range, ICU LOS intensive care unit length of stay, $R C P C H$ Royal College of Paediatrics and Children Health, $C D C$ The Centers for Disease Control and Prevention, WHO World Health Organization, NYSDOH New York State Department of Health

${ }^{a}$ Coexisting conditions such as chronic lung disease obesity, and immunocompromising conditions

${ }^{\mathrm{b}}$ Upper respiratory tract infection

${ }^{\mathrm{c}}$ Lower respiratory tract infection

disease progression and invasive treatment is a particularly pressing question. This includes if early non-invasive respiratory support can prevent future intubation. It is not known if emerging viral variants are able to induce a similar set of symptoms, or how they may affect patient outcomes. For those who have recovered, the long-term sequelae, especially among patients who experienced cardiac dysfunction and coronary aneurysms, is not known. Long-term outcomes are particularly critical to understand with the pediatric population of MIS-C.

\section{Conclusions}

MIS-C is a new clinical syndrome that has emerged as a result of the COVID-19 pandemic. Although a minor proportion of children who are infected with COVID-19 progress to MIS-C, the clinical manifestations can be severe. As second and third waves of COVID-19 are progressing worldwide, anesthesiologists and intensivists are likely to treat an increasing number of children with MIS-C. As research into treatments is ongoing [37], pragmatic trials and investigations are needed that will provide more rapid answers to important clinical treatment questions.

Supplementary Information The online version contains supplementary material available at https://doi.org/10.1007/s00540-021-02952-6.

Acknowledgements KA and JTM acknowledge the Department of Anesthesiology and Pain Medicine, University of Toronto, and the Hospital for Sick Children, for secured academic time to conduct the current work and as recipients of Merit Awards.
Author contributions NS and KA conceived this paper. NS, KA, and ME conducted a literature search. NS and KA wrote the first draft of the manuscript. All authors wrote subsequent iterations of the manuscript, and approved the final manuscript. NS and KA equally contributed to the paper as a principal author.

Funding This work was supported by Perioperative Services Facilitator Grant Program 2020-2021, Hospital for Sick Children.

\section{Declarations}

Conflict of interest The authors declare that they have no competing interests related to this publication.

\section{References}

1. Gai N, Maynes JT, Aoyama K. Unique challenges in pediatric anesthesia created by COVID-19. J Anesth (Springer Singapore). 2020; 35:345-50

2. Feldstein LR, Rose EB, Horwitz SM, Collins JP, Newhams MM, Son MBF, Newburger JW, Kleinman LC, Heidemann SM, Martin AA, Singh AR, Li S, Tarquinio KM, Jaggi P, Oster ME, Zackai SP, Gillen J, Ratner AJ, Walsh RF, Fitzgerald JC, Keenaghan MA,Alharash H, Doymaz S, Clouser KN, Giuliano JS Jr, Gupta A, Parker RM, Maddux AB, Havalad V, Ramsingh S, Bukulmez H, Bradford TT, Smith LS, Tenforde MW, Carroll CL, Riggs BJ, Gertz SJ, Daube A, Lansell A, Coronado Munoz A, Hobbs CV, Marohn KL, Halasa NB, Patel MM, Randolph AG; Overcoming COVID-19 Investigators; CDC COVID-19 Response Team. Multisystem inflammatory syndrome in US children and adolescents. N Engl J Med (US). 2020;383:334-46.

3. Riphagen S, Gomez X, Gonzalez-Martinez C, Wilkinson N, Theocharis P. Hyperinflammatory shock in children during COVID-19 pandemic. Lancet (London, England). 2020;395:1607-8.

4. Qiu H, Wu J, Hong L, Luo Y, Song Q, Chen D. Clinical and epidemiological features of 36 children with coronavirus disease 2019 
(COVID-19) in Zhejiang, China: an observational cohort study. Lancet Infect Dis (Lancet Publishing Group). 2020;20:689-96.

5. Wu Z, McGoogan JM. Characteristics of and important lessons from the coronavirus disease 2019 (COVID-19) Outbreak in China: summary of a report of 72314 cases from the Chinese Center for Disease Control and Prevention. JAMA J Am Med Assoc. 2020;323:1239-42.

6. Lu X, Zhang L, Du H, Zhang J, Li YY, Qu J, Zhang W, Wang Y, Bao S, Li Y, Wu C, Liu H, Liu D, Shao J, Peng X, Yang Y, Liu Z,Xiang Y, Zhang F, Silva RM, Pinkerton KE, Shen K, Xiao $\mathrm{H}$, Xu S, Wong GWK; Chinese Pediatric Novel Coronavirus Study Team. SARS-CoV-2 infection in children. N Engl J Med. 2020;382:1663-5.

7. Shekerdemian LS, Mahmood NR, Wolfe KK, Riggs BJ, Ross CE, McKiernan CA, Heidemann SM, Kleinman LC, Sen AI, Hall MW,Priestley MA, McGuire JK, Boukas K, Sharron MP, Burns JP; International COVID-19 PICU Collaborative. Characteristics and outcomes of children with coronavirus disease 2019 (COVID19) infection admitted to US and Canadian pediatric intensive care units. JAMA Pediatr. 2020;174:868-73.

8. Dufort EM, Koumans EH, Chow EJ, Rosenthal EM, Muse A, Rowlands J, Barranco MA, Maxted AM, Rosenberg ES, Easton D, Udo T, Kumar J, Pulver W, Smith L, Hutton B, Blog D, Zucker H; New York State and Centers for Disease Control and Prevention Multisystem Inflammatory Syndrome in Children Investigation Team. Multisystem inflammatory syndrome in children in New York State. Aldrich ML Barney GR, Bitley S, Bruce EM, Cogan L, Cook S, Choueiter NF, Friedrich M, Gewitz M, Holtgrave DR, Kuhles D, Lighter J, Milner JD, Newman A, Ofori-Amanfo G, Rubin LG, Schneider J, Sottolano D, Sommer J, Spina N, Wester R, Wilson KM, Zachariah AJ, editor. N Engl J Med (US). 2020;383:347-58.

9. Davies P, Evans C, Kanthimathinathan HK, Lillie J, Brierley J, Waters G, Johnson M, Griffiths B, du Pré P, Mohammad Z, Deep A, Playfor S, Singh D, Inwald D, Jardine M, Ross O, Shetty N, Worrall M, Sinha R, Koul A, Whittaker E, Vyas H, Scholefield BR, Ramnarayan P. Intensive care admissions of children with paediatric inflammatory multisystem syndrome temporally associated with SARS-CoV-2 (PIMS-TS) in the UK: a multicentre observational study. Lancet Child Adolesc Health (England). 2020;4:669-77.

10. Whittaker E, Bamford A, Kenny J, Kaforou M, Jones CE, Shah P, Ramnarayan P, Fraisse A, Miller O, Davies P, Kucera F, Brierley J, McDougall M, Carter M, Tremoulet A, Shimizu C, Herberg J, Burns JC, Lyall H, Levin M; PIMS-TS Study Group and EUCLIDS and PERFORM Consortia. Clinical characteristics of 58 children with a pediatric inflammatory multisystem syndrome temporally associated with SARS-CoV-2. JAMA (US). 2020;324:259-69.

11. Fernandes DM, Oliveira CR, Guerguis S, Eisenberg R, Choi J, Kim M, Abdelhemid A, Agha R, Agarwal S, Aschner JL, Avner JR,Ballance C, Bock J, Bhavsar SM, Campbell M, Clouser KN, Gesner M, Goldman DL, Hammerschlag MR, Hymes S, Howard A, Jung HJ, Kohlhoff S, Kojaoghlanian T, Lewis R, Nachman S, Naganathan S, Paintsil E, Pall H, Sy S, Wadowski S, Zirinsky E, Cabana MD, Herold BC; Tri-State Pediatric COVID-19 Research Consortium. Severe acute respiratory syndrome coronavirus 2 clinical syndromes and predictors of disease severity in hospitalized children and youth. J Pediatr (US). 2021;230:23-31.e10.

12. Antúnez-Montes OY, Escamilla MI, Figueroa-Uribe AF, ArteagaMenchaca E, Lavariega-Saráchaga M, Salcedo-Lozada P, Melchior P, de Oliveira RB, Tirado Caballero JC, Redondo HP, Montes Fontalvo LV, Hernandez R, Chavez C, Campos F, Uribe F, DelAguila O, Rios Aida JA, Buitrago AP, Betancur Londoño LM, Mendoza Vega LF, Hernández CA, Sali M, Higuita Palacio JE, Gomez-Vargas J, Yock-Corrales A, Buonsenso D. COVID-19 and multisystem inflammatory syndrome in Latin American children: a multinational study. Pediatr Infect Dis J (US). 2021;40:e1-6.

13. Bunyavanich S, Do A, Vicencio A. Nasal gene expression of angiotensin-converting enzyme 2 in children and adults. JAMA. 2020;323:2427-9.

14. Park A, Iwasaki A. Type I and type III interferons-induction, signaling, evasion, and application to combat COVID-19. Cell Host Microbe. 2020;27:870-8.

15. Diorio C, Henrickson SE, Vella LA, McNerney KO, Chase J, Burudpakdee C, Lee JH, Jasen C, Balamuth F, Barrett DM, Banwell BL, Bernt KM, Blatz AM, Chiotos K, Fisher BT, Fitzgerald JC, Gerber JS, Gollomp K, Gray C, Grupp SA, Harris RM, Kilbaugh TJ, John ARO, Lambert M, Liebling EJ, Paessler ME, Petrosa W, Phillips C, Reilly AF, Romberg ND, Seif A, Sesok-Pizzini DA, Sullivan KE, Vardaro J, Behrens EM, Teachey DT, Bassiri $\mathrm{H}$. Multisystem inflammatory syndrome in children and COVID19 are distinct presentations of SARS-CoV-2. J Clin Invest (US). 2020;130:5967-75.

16. Cheng MH, Zhang S, Porritt RA, Noval Rivas M, Paschold L, Willscher E, Binder M, Arditi M, Bahar I. Superantigenic character of an insert unique to SARS-CoV-2 spike supported by skewed TCR repertoire in patients with hyperinflammation. Proc Natl Acad Sci USA. 2020;117:25254-62.

17. Valverde I, Singh Y, Sanchez-de-Toledo J, Theocharis P, Chikermane A, Di Filippo S, Kuciñska B, Mannarino S, Tamariz-Martel A, Gutierrez-Larraya F, Soda G, Vandekerckhove K, GonzalezBarlatay F, McMahon CJ, Marcora S, Napoleone CP, Duong P, Tuo G, Deri A, Nepali G, Ilina M, Ciliberti P, Miller O; AEPC COVID-19 Rapid Response Team. Acute cardiovascular manifestations in 286 children with multisystem inflammatory syndrome associated with COVID-19 infection in Europe. Circulation [Ovid Technologies (Wolters Kluwer Health)]. 2021;143:21-32.

18. Deep A, Upadhyay G, du Pré P, Lillie J, Pan D, Mudalige N, Kanthimathinathan HK, Johnson M, Riphagen S, Dwarakanathan B, Raffaj D, Sundararajan S, Davies P, Mohammad Z, Shetty N, Playfor S, Jardine M, Ross O, Levin R, Waters G, Sinha R, Scholefield BR, Boot E, Koul A, Freire-Gomez X, Ramnarayan P. Acute Kidney injury in pediatric inflammatory multisystem syndrome temporally associated with severe acute respiratory syndrome coronavirus-2 pandemic: experience from PICUs across United Kingdom. Crit Care Med (US). 2020;48:1809-18

19. Miller J, Cantor A, Zachariah P, Ahn D, Martinez M, Margolis KG. Gastrointestinal symptoms as a major presentation component of a novel multisystem inflammatory syndrome in children that is related to coronavirus disease 2019: a single center experience of 44 cases. Gastroenterology (US). 2020;159:1571-1574.e2.

20. Multisystem inflammatory syndrome in children and adolescents temporally related to COVID-19 [Internet]. [cited 2021 Jan 12]. Available from: https://www.who.int/news-room/commentaries/ detail/multisystem-inflammatory-syndrome-in-children-and-adole scents-with-covid- 19 .

21. Information for Healthcare Providers about multisystem inflammatory syndrome in children (MIS-C) I CDC [Internet]. [cited 2021 Jan 12]. Available from: https://www.cdc.gov/mis-c/hcp/.

22. Paediatric multisystem inflammatory syndrome temporally associated with COVID-19 (PIMS) - guidance for clinicians I RCPCH [Internet]. [cited 2021 Jan 12]. Available from: https://www.rcpch. ac.uk/resources/paediatric-multisystem-inflammatory-syndrometemporally-associated-covid-19-pims-guidance.

23. Paediatric inflammatory multisystem syndrome temporally associated with COVID-19 I Canadian Paediatric Society [Internet]. [cited 2021 Jan 12]. Available from: https://www.cps.ca/docum ents/position/pims.

24. Nakra NA, Blumberg DA, Herrera-Guerra A, Lakshminrusimha S. Multi-System Inflammatory Syndrome in Children (MIS-C) following SARS-CoV-2 infection: review of clinical presentation, 
hypothetical pathogenesis, and proposed management. Children. 2020;7:69.

25. Singh S, Jindal AK, Pilania RK. Diagnosis of Kawasaki disease. Int J Rheum Dis. 2018;21:36-44.

26. Kobayashi T, Ayusawa M, Suzuki H, Abe J, Ito S, Kato T, Kamada M, Shiono J, Suda K, Tsuchiya K, Nakamura T, Nakamura Y, Nomura Y, Hamada H, Fukazawa R, Furuno K, Matsuura H, Matsubara T, Miura M, Takahashi K. Revision of diagnostic guidelines for Kawasaki disease (6th revised edition). Pediatr Int (Blackwell Publishing). 2020;62:1135-8.

27. McCrindle BW, Rowley AH, Newburger JW, Burns JC, Bolger AF, Gewitz M, Baker AL, Jackson MA, Takahashi M, Shah PB, Kobayashi T, Wu MH, Saji TT, Pahl E; American Heart Association Rheumatic Fever, Endocarditis, and Kawasaki Disease Committee of the Council on Cardiovascular Disease in the Young; Council on Cardiovascular and Stroke Nursing; Council on Cardiovascular Surgery and Anesthesia; and Council on Epidemiology and Prevention. Diagnosis, treatment, and long-term management of Kawasaki disease: a scientific statement for health professionals from the American Heart Association. Circulation. 2017. https:// doi.org/10.1161/CIR.0000000000000484.

28. Verdoni L, Mazza A, Gervasoni A, Martelli L, Ruggeri M, Ciuffreda M, Bonanomi E, D'Antiga L. An outbreak of severe Kawasaki-like disease at the Italian epicentre of the SARS-CoV-2 epidemic: an observational cohort study. Lancet (London, England). 2020;395:1771-8.

29. Sperotto F, Friedman KG, Son MBF, VanderPluym CJ, Newburger JW, Dionne A. Cardiac manifestations in SARS-CoV-2-associated multisystem inflammatory syndrome in children: a comprehensive review and proposed clinical approach. Eur J Pediatr (Germany). 2020;180:307-22.

30. Hennon TR, Penque MD, Abdul-Aziz R, Alibrahim OS, McGreevy MB, Prout AJ, Schaefer BA, Ambrusko SJ, Pastore JV, Turkovich SJ, Gomez-Duarte OG, Hicar MD. COVID-19 associated multisystem inflammatory syndrome in children (MIS-C) guidelines; a Western New York approach. Prog Pediatr Cardiol (Elsevier Ireland Ltd). 2020. https://doi.org/10.1016/j.ppedcard. 2020.101232.

31. Henderson LA, Canna SW, Friedman KG, Gorelik M, Lapidus SK, Bassiri H, Behrens EM, Ferris A, Kernan KF, Schulert GS, Seo P, Son MBF, Tremoulet AH, Yeung RSM, Mudano AS, Turner AS, Karp DR, Mehta JJ. American College of Rheumatology clinical guidance for pediatric patients with multisystem inflammatory syndrome in children (MIS-C) associated with SARS-CoV-2 and hyperinflammation in COVID-19. Version 2. Arthritis Rheumatol (Wiley). 2020;72:1791-805.

32. Hoste L, Van Paemel R, Haerynck F. Multisystem inflammatory syndrome in children related to COVID-19: a systematic review. Eur J Pediatr. 2021. https://doi.org/10.1007/s00431-021-03993-5.
33. Cattalini M, Taddio A, Bracaglia C, Cimaz R, Paolera SD, Filocamo G, La Torre F, Lattanzi B, Marchesi A, Simonini G, Zuccotti G, Zunica F, Villani A, Ravelli A; Rheumatology Study Group of the Italian Society of Pediatrics. Childhood multisystem inflammatory syndrome associated with COVID-19 (MIS-C): a diagnostic and treatment guidance from the Rheumatology Study Group of the Italian Society of Pediatrics. Ital J Pediatr (Springer Science and Business Media LLC). 2021. https://doi.org/10.1186/ s13052-021-00980-2.

34. Feldstein LR, Tenforde MW, Friedman KG, Newhams M, Rose EB, Dapul H, Soma VL, Maddux AB, Mourani PM, Bowens C, Maamari M, Hall MW, Riggs BJ, Giuliano JS Jr, Singh AR, Li S, Kong M, Schuster JE, McLaughlin GE, Schwartz SP, Walker TC, Loftis LL, Hobbs CV, Halasa NB, Doymaz S, Babbitt CJ, Hume JR, Gertz SJ, Irby K, Clouser KN, Cvijanovich NZ, Bradford TT, Smith LS, Heidemann SM, Zackai SP, Wellnitz K, Nofziger RA, Horwitz SM, Carroll RW, Rowan CM, Tarquinio KM, Mack EH, Fitzgerald JC,Coates BM, Jackson AM, Young CC, Son MBF, Patel MM, Newburger JW, Randolph AG; Overcoming COVID19 Investigators. Characteristics and outcomes of US children and adolescents with multisystem inflammatory syndrome in children (MIS-C) compared with severe acute COVID-19. JAMA (US). 2021;325:1074-87.

35. Abrams JY, Oster ME, Godfred-Cato SE, Bryant B, Datta SD, Campbell AP, Leung JW, Tsang CA, Pierce TJ, Kennedy JL, Hammett TA, Belay ED. Factors linked to severe outcomes in multisystem inflammatory syndrome in children (MIS-C) in the USA: a retrospective surveillance study. Lancet Child Adolesc Health (England). 2021;5:323-31.

36. Bautista-Rodriguez C, Sanchez-de-Toledo J, Clark BC, Herberg J, Bajolle F, Randanne PC, Salas-Mera D, Foldvari S, Chowdhury D, Munoz R, Bianco F, Singh Y, Levin M, Bonnet D, Fraisse A. Multisystem inflammatory syndrome in children: an international survey. Pediatrics (US). 2021;147:e2020024554.

37. NIH funds eight studies to uncover risk factors for COVID-19-related inflammatory syndrome in children I National Institutes of Health (NIH) [Internet]. [cited 2021 Jan 12]. Available from: https://www.nih.gov/news-events/news-releases/nih-funds-eightstudies-uncover-risk-factors-covid-19-related-inflammatory-syndr ome-children.

Publisher's Note Springer Nature remains neutral with regard to jurisdictional claims in published maps and institutional affiliations. 